\title{
Proposals for Equitable Governance and Management of Natural Resources in Nigeria
}

\author{
Z. Adangor ${ }^{1}$ \\ ${ }^{1}$ Department of Public Law, Faculty of Law, Rivers State University, Port Harcourt, Nigeria \\ Correspondence: Z. Adangor, PhD (Aberdeen), BL, MCIArb, Associate Professor, Department of Public Law, \\ Faculty of Law, Rivers State University, Port Harcourt, Nigeria. E-mail: adango.zaccheus@ust.edu.ng; \\ adazaky@yahoo.com
}

\author{
Received: October 16, $2017 \quad$ Accepted: January 3, $2018 \quad$ Online Published: February 28, 2018 \\ doi:10.5539/ilr.v7n1p213 \\ URL: https://doi.org/10.5539/ilr.v7n1p213
}

\begin{abstract}
The current regime of centralized natural resource governance poses one of the greatest threats to the stability of the Federation of Nigeria. The centralization of natural resource ownership and government is perceived by the ethnic minorities of the oil-producing Niger Delta Region of Nigeria as a tool of ethnic domination by the majority ethnic groups. Given the centrality of natural resources to the growth of Nigeria's economy and the desirability of maintaining a stable federation, this research seeks to propose an equitable regime of natural resource governance that recognises and accommodates both national and regional interest in Nigeria's abundant natural resources and thereby strengthens federal stability. This paper which adopts analytical and comparative research methodologies, argues that the current regime of natural resource governance in Nigeria is divisive and that only the participation of the federating states in the governance of natural resources exploited within their respective geographic boundaries would conduce to peace and inter-regional harmony and enhance the capacities of the federating states to develop at their varying speed according to the dreams of the Founding Fathers of Nigerian federalism. The paper concludes by recommending resource federalism whereby competence over natural resource governance could be shared between the federal government and the federating states.
\end{abstract}

Keywords: governance, natural resources, Nigeria, resource federalism

\section{Introduction}

Nigeria is a natural resource-dependent nation with earnings from natural resources constituting the mainstay of the economy. The term 'natural resources' may be defined as any inorganic "material in its native state which when extracted has economic value." The term has also been defined as "deposits of minerals, water and other materials furnished by nature." ${ }^{2}$ Natural resources include gold, iron ore, mineral oils, natural gas, coal, copper, bituminous shales, tar sands, bauxite and other products of nature with economic value.

The major characteristics of natural resources is that they are products of nature with economic value in contrast to agricultural products such as livestock, hide and skin, horns, groundnuts, beans, grains, cotton and gum which are the "direct result of husbandry and the cultivation of the soil." Therefore, within the context of this work, the term 'natural resources' is used to describe minerals, mineral oils and natural gas. ${ }^{4}$

Nigeria is endowed with abundant deposits of minerals, mineral oils and natural gas. Since the 1970's, Nigeria's economy has been driven by revenue derived from oil and natural gas. The near-total dependence of the economy on oil revenues is easily noticeable from the fact that the annual federal budget is traditionally based on the daily production level and benchmark oil price in the international market. This explains why any drop in the price of oil in the international market is bound to have adverse impact on the economy of Nigeria.

Available statistics shows that oil proceeds account for the bulk of budgetary revenue. ${ }^{5}$ From a meagre

\footnotetext{
${ }^{1}$ A-G Federation v. A-G Abia State (No. 2) [2002] 6 NWLR (Part 764) 542, 670-671.

${ }^{2}$ McGraw Hill and Sybil P. Parker, McGraw-Hill Dictionary of Scientific \& Technical Terms (6th edn, McGraw-Hill Companies Inc., New York 2003) 100; Phillip Keary, The New Penguin Dictionary of Geology (2nd edn Penguin Books, 2003) 130.

${ }^{3}$ Bryan A. Garner et al (eds.), Black's Law Dictionary (8th edn., Thomson West Publishing Co., Dallas Texas 2004) 1056.

${ }^{4}$ Richard Cullen, 'The encounter between natural resources and federalism in Canada and Australia' (1990) 24 Brit. Colum. L. Rev. 275 , 276.

${ }^{5}$ Report of Technical Committee on the Niger Delta, Volume I ((Abuja, November 2008) 6.
} 
contribution of 18.9 per cent to the national budget in 1970, the relative contribution of the oil and gas sector soared to 80.7 per cent in 1974 and by 1989, its contribution stood at 82.2 per cent. By 2011 the share of revenue from oil and gas in total government receipts stood at 79.9 per cent which represented a drop from 85.6 per cent recorded in 2004 and 85.8 per cent recorded in 2005 respectively. ${ }^{6}$ A report published by the Nigeria Extractive Industries Transparency Initiative (NEITI) shows that the total financial flows from the oil and gas industry to the Federation account and other federal agencies from 2009-2011 amounted to $\$ 143.5$ billion. This is against the audit total of $\$ 148.8$ billion which the sector generated from 2006-2008. ${ }^{7}$ In 2012 , the total financial flows from all sources in the oil and gas sector of the extractive industry stood at $\$ 62.944$ billion. ${ }^{8}$ Oil is also the major source of foreign exchange earnings for the country. According to the Central Bank of Nigeria, the sector accounted for 90.6 per cent of the total inflow of foreign exchange in 2008 compared to its performance in 2007 which stood at 82.5 per cent. $^{9}$

Although the contribution of the oil and gas sector to the Gross Domestic Product (GDP) and federally-collected revenue had dropped in 2015 to 4.0 per cent and 55.4 per cent respectively, due largely to the persistent drop in the price of crude oil in the international market and the decline in crude oil production and exports, ${ }^{10}$ the sector still sustains the economy and the conduct of governmental affairs at all levels so much so that the drop in the price of oil in the international market triggered the economic recession being experienced in the country.

Given the indispensability of natural resources to the sustainability of the Federation of Nigeria and the uneven geographical location of these resources, their governance, control and management have always been a major source of contention not only between the federal and state governments but also amongst the disparate ethnic nationalities in the Federation. There is ingrained fear that the concentration of ownership and governance rights over natural resources in the federal government could be exploited by the politically advantaged region(s) or ethnic groups as a tool of ethnic domination against the natural resource-bearing region(s) or ethnic groups. This fear, which cannot be wished away, accounts for much of the ethnic tension and threats to the stability of the federation.

This paper examines the current governance structure of natural resources in Nigeria and argues that the centralization of natural resource ownership and governance is unjust, inequitable and divisive for a multi-ethnic federation like Nigeria founded on the underlying principle that no region should suffer domination. It is further argued that the exclusion of the oil and gas producing states and/or oil bearing communities from the management structure of natural resources ensures that the adverse impacts of natural resource exploration and exploitation on the natural resource-bearing regions and communities and other social, cultural and economic externalities associated with resource extraction are not addressed. The paper proposes a new governance regime for natural resources in Nigeria that accommodates both national and regional interest.

The study is structured into six sections. The background to the study is provided in the introductory section while section two examines the natural resource endowments of Nigeria and the drift in the federal government policy focus from solid minerals to oil and gas. In section three, the extant governance and management structure for natural resources is examined whilst its inequities are discussed in the fourth section. Proposals for a new governance structure and the concluding remarks are set out in the fifth and sixth sections respectively.

\section{Nigeria's Natural Resource Deposits}

As already mentioned, Nigeria's natural resource endowments may be broadly categorise into solid minerals and oil and gas. According to the Federal Ministry of Mines and Steel Development, there are 34 types of solid

\footnotetext{
${ }^{6}$ Central Bank of Nigeria (CBN), Annual Report and Financial Statement $2005<\mathrm{http}: / /$ www.cenbank.org > accessed September 10, 2017; International Monetary Fund (IMF), Guide on Resource Revenue Transparency (IMF, Washington, D. C. 2007)62<http://www.imf.org/external/np/pp/2007/eng/051507g.pdf. >accessed October 11, 2017; Central Bank of Nigeria, 'Annual Report 2011' (Abuja, July 2012)<http://www.cenbank.org/ documents/ annualreport.asp/> accessed 29 July 2017; during the first half of 2012, oil revenue constituted 78.1 per cent of the total federal receipts, see Central Bank of Nigeria, 'Economic Report for the first half of 2012' (Abuja, 2012)<http://www.cenbank.org/out/2012/ccd/2012\%20half\%20year\%report.pdf/ >accessed 30 July 2017.

${ }^{7}$ Nigeria Extractive Industries Transparency Initiative (NEITI), 'Financial Audit: An Independent Report Assessing and Reconciling Financial Flows within Nigeria's Oil and Gas Industry-2009-2011' (Abuja 2013) $<$ http://www.eiti.org/files/NEITI-EITI-Core-Audit-Report-Oil-Gas-2009-2011-310113-New_4.pdf/>accessed 30 July 2017.

${ }^{8}$ NEITI, "Financial, Physical and Process Audit-An Independent Report Assessing and Reconciling Physical and Financial Flows within Nigeria's Oil and Gas Industry-2012>://www.neiti.org.ng/sites/default/files/pdf/2012-oil-Gas-Audit-Report-Comprehensive-pdf> accessed $16^{\text {th }}$ August, 2017.

${ }^{9}$ Central Bank of Nigeria (CBN), 'Annual Report and Financial Statement 2008' (Abuja 2009)< http://www.cenbank.org>accessed 20 September 2017.

${ }^{10}$ Central Bank of Nigeria, Annual Reports 2015 (Abuja, 2016) 109.
} 
minerals in Nigeria occurring in more than 450 locations all over the 36 states of the federation and the Federal Capital Territory. ${ }^{11}$ Some of the known mineral resources found in different regions of the federation include gold, coal, zinc, granite, clay, marble, silver, bitumen, talc, iron ore, lead, limestone, diatomite, bentonite, gypsum, manganese, magnesite and phosphate. ${ }^{12}$ The proved reserves of these solid minerals attest to the enormous mineral endowment of the country. For instance, the proved reserve of iron ore is over 3 billion tonnes while the occurrence of bitumen deposits is estimated at about 42 billion tones, almost as twice the amount of existing reserves of crude oil. Similarly, about 1 billion tonnes of gypsum deposits and over 100 million tonnes of talc, respectively, are spread over many states of the federation. ${ }^{13}$

Prior to the discovery of crude oil, Nigeria's economy was driven by agriculture and solid minerals with records of mining of solid minerals like tin, mica, zinc and monazite dating back to pre-colonial period. ${ }^{14}$ Amongst several other mineral commodities, coal and tin were mined on a massive scale. Significant foreign exchange was earned from the export of lead and zinc and Nigeria was the world's largest producer of columbite accounting for 94 percent of its world production at a certain point in time. ${ }^{15}$

The decline of the solid mineral sector, which dates back to late 1970, could be traced to the discovery of petroleum which replaced solid minerals as the nation's main foreign exchange earner. It is very arguable that the discovery of crude oil has considerably stymied government's initiatives in the solid minerals sector in terms of policy formulation, institutional support, regulation, and funding, thus leaving the sector completely neglected. ${ }^{16}$ The launch of the new National Policy on Solid Minerals Development, establishment of the Solid Minerals Development Fund and introduction of a liberal tax regime are part of recent efforts by the federal government to reverse the declining fortune of the sector. ${ }^{17} \mathrm{~A}$ recent report suggests that these policies have generated an increase in the aggregate output of solid minerals by 11.1 percent to 53.61 million tonnes in $2011 .^{18}$

With respect to the petroleum sector, oil was first struck in commercial quantities by Shell B-P at Oloibiri in the Niger Delta region of Nigeria in $1956 .{ }^{19}$ Nigeria successfully joined the ranks of oil-producing nations with her first shipment of crude oil in 1958 when the Oloibiri oil field "came on stream producing 5,100 bpd. ${ }^{20}$ New discoveries were made by Shell at Afam, Ebubu, Bomo, and other parts of Ogoni land all in the Niger delta, thus raising the prospects of an emerging viable oil industry. ${ }^{21}$

It would appear that the discovery of more oil fields outside Oloibiri, impelled the British colonial government to change her sole concessionary policy by repealing section 6(1)(a) of the Mineral Oils Ordinance 1914 which barred non-British companies from obtaining exploration licence to prospect for oil in Nigeria. ${ }^{22}$ Pursuant to the repeal, the sole concessionary right granted to Shell-BP was revoked and oil exploration licences covering onshore and offshore areas were granted to other International Oil Companies (IOCs) including Agip Oil Company (Italian), Safrap which later became Elf (French), Gulf Oil Company (now Chevron), Tenneco and

11 Ministry of Mines and Steel Development, The Solid Minerals Sector: Our 34 types of minerals http://www.mmsd.gov.ng/solid minerals sector/34 minerals.asp> accessed October 10, 2017.

${ }^{12}$ Ministry of Mines and Steel Development (n11) 3.

${ }^{13}$ Corporate Nigeria: 'The business, trade and investment guide 2010/2011' (2010)202< http://www.corporate_nigeria.net >accessed October 2, 2017; Kaniye S.A. Ebeku, 'Overview of Nigeria's minerals and mining law' (2004) 6 I.E.L.T.R. 129, 130-131.

${ }^{14}$ Gilbert Stone, The Mining Laws of the British Empire and of foreign countries Vol.1 Nigeria (H.M.S.O., London 1920) 1-2; T.O. Elias, Nigerian Land Law and Custom (3rd edn., Routledge \& Regan Paul Ltd., London 1960) 59.

${ }^{15}$ Ministry of Mines and Steel Development, National Minerals and Metal Policy (Abuja-Nigeria, January 2008) 3.

${ }^{16}$ Ministry of Mines and Steel Development (n11) 4.

${ }^{17}$ Ministry of Mines and Steel Development (n11) 4-5.

${ }^{18}$ Central Bank of Nigeria, 'Annual report 2011' (Abuja, July 2012) 159.

http://www.cenbank.org/AR2011/DEFAULT/ASP> accessed August 10, 2017.

${ }^{19}$ Martin M. Olisa, Nigerian Petroleum Law and Practice (2 ${ }^{\text {nd }}$ edn Jonia Ventures Limited, Lagos 1997) 2.

20 Nigerian National Petroleum Corporation (NNPC), 'History of the Nigerian Petroleum Industry'< http://www.nnpcgroup.com/NNPCBusiness/BusinessInformation/OilGasinNigeria/IndustryHistory.aspx >accessed September 30, 2017.

${ }^{21}$ M. O. Feyide, Oil in World Politics (Lagos University Press, Lagos 1987) 18; Nigeria's proved oil reserves at the end of 2016 stood at 37.1 billion barrels representing $2.2 \%$ of world's total reserves and the $11^{\text {th }}$ largest in the world. The country's proved natural gas reserves at the end of 2016 were no less impressive. They stood at 5.3 trillion cubic metres representing $2.9 \%$ of world's total reserves and the $9^{\text {th }}$ largest in the world. This represented an improvement on the estimated reserves for 1991 and 2001 which stood at 3.4 trillion cubic metres and 4.6 trillion cubic metres respectively, see BP Statistical Review of World Energy (June 2017) $<$ http://www.bp.com/content/dam/bp/en/corporate/pdf/energy-economics/Statistical-review-2017/BP-statistical-review-of-world-energy-201 7-full-report-pdf/>accessed 10 October, 2017.

${ }^{22}$ No. 17 of 1914; the repeal was effected by section 2 of the Mineral Oils (Amendment) Act 1958; Kaniye S. A. Ebeku, Oil and the Niger Delta People in International Law (Rudiger Koppe Verlag, Koln. Germany 2006)68. 
Amoseas (now Texaco and Chevron respectively); and Mobil Exploration Nigeria Limited. ${ }^{23}$ This development increased the pace of exploration activities in the Niger delta and led to substantial increase in production level of over 2 million bpd by the late sixties and early seventies. ${ }^{24}$

Unarguably, all of Nigeria's oil and gas are currently produced from land and swamps in the Niger delta and from deep-water reserves some 120 kilometres off its coast. There are currently 606 oil fields in the region out of which 355 are on-shore while the remaining 251 are offshore. ${ }^{25}$ The operations of Shell Petroleum Development Company Limited (SPDC) in the region alone are spread over circa 20,000 square kilometres comprising a 'network of more than 6,000 kilometres of flow lines and pipelines, about 60 producing oil fields, approximately 700 producing wells, 46 flow stations, seven gas plants, and two major oil export terminals at Bonny and Forcados. ${ }^{26}$ The Niger delta region is thus the sole host to all of Nigeria's oil exploration and production activities and the hub of the nation's oil and gas industry.

However, there are indications from recent geological studies that 'potentials to add to the nation's current reserves exist in sedimentary basins within several other states of Nigeria. ${ }^{27}$ In furtherance of these studies, 28 exploratory wells have been drilled outside of the Niger Delta region showing various levels of prospectivity. ${ }^{28}$ The existence of these sedimentary basins, namely Anambra, Benue Trough, Chad, Sokoto, Bida, and the Dahomey raises the prospect that virtually every region of the federation may in the near future, contribute to the nation's oil and gas reserves thereby breaking the monopoly of the Niger delta as the sole oil and gas producing region of the federation.

With the current production level of 2.48 million bpd (representing $2.9 \%$ of the world total daily production), Nigeria is the $11^{\text {th }}$ largest world producer of crude oil and Africa's largest. ${ }^{29}$ Nigeria's proved oil reserves at the end of 2016 stood at 37.1 billion barrels representing $2.2 \%$ of world's total reserves and the $11^{\text {th }}$ largest in the world. $^{30}$ The country's proved natural gas reserves as at the end of 2013 were no less impressive. They stood at 5.3 trillion cubic metres representing $2.9 \%$ of world's total reserves and the $9^{\text {th }}$ largest in the world. This represents an improvement on the estimated reserves for the past three decades which stood at 2.83 trillion cubic metres in 1989, 3.51 trillion cubic metres in 1999 and 5.25 trillion cubic metres in 2009 respectively. ${ }^{31}$

\section{Current Ownership and Governance Regime of Natural Resources}

Under Nigeria's extant legal order, the entire property in natural resources, whether onshore or offshore, including their governance, control and management are vested exclusively in the federal government. The first comprehensive post-independence legislation enacted by the former federal military government to regulate the operation of the Nigerian petroleum industry was the Petroleum Decree (now Act), 1969. Section 1(1) \& (2) of the Petroleum Act vests exclusive ownership of petroleum resources in the federal government in explicit terms:

S.1 (1) The entire ownership and control of all petroleum in, under or upon any lands to which this section applies shall be vested in the State.

(2) This section applies to all land (including land covered by water) which-

\footnotetext{
${ }^{23}$ G. Etikerentse, Nigerian Petroleum Law (2 ${ }^{\text {nd }}$ edn Dredew Publishers, 2004)8; M. Ajomo, 'Law and Changing Policy in Nigeria's Oil Industry' in J.A. Omotola (ed), Law and Development (University of Lagos Press, Lagos 1987) 86; Adelaja Odutola Odukoya, 'Oil and Sustainable Development in Nigeria: A case study of the Niger Delta' (2006) 20 J. Hum. Ecol. 249, 250.

${ }^{24}$ NNPC (n20).

25 Amnesty International, Nigeria: Petroleum, Pollution and Poverty in the Niger Delta (June 2009) 11 http://www.amnesty.org/en/library/asset/. . /017/. . ./afr440172009.pdf < accessed 23 September, 2017; Report of the Technical Committee on the Niger Delta Volume 1 (n5) 6; NNPC, 'Development of Nigeria's Oil Industry'< http:www.nnpcgroup.com/NNPCBusiness/BusinessInformation/OilGasinNigeria/DevelopmentoftheIndustry.aspx>accessed 21 July, 2017.

${ }^{26}$ SPDC, 'Briefing Notes: Shell Interests in Nigeria (April 2014)<http://www.s07static-shell.com/ content/dam/

shell-new/local/country/nga/downloads/pdf/2014bnotes/shell-interests.pdf $>$ accessed 03 August, 2017; Amnesty International (n25); Report of the Technical Committee on the Niger Delta Volume (n5).

${ }^{27}$ Nuhu George Obaje, Geology and Mineral Resources of Nigeria (Springer Dordrecht Heidelberg, London 2009)3.

${ }^{28}$ These wells include 2 discovery wells in Anambra State, 1 discovery well each in Edo and Benue States and 24 wells in Chad Basin, NNPC (n 20).

29 BP Statistical Review of World $\quad$ Energy $\quad$ (June 2017$) 12, \quad 26$ $<$ http://www.bp.com/content/dam/bp/en/corporate/pdf/energy-economics/Statistical-review-2017/BP-statistical-review-of-world-energy-201 7-full-report-pdf/>accessed 10 October, 2017; Nigerian National Petroleum Corporation, '2012 Annual Statistical Bulletin'< http://www.nnpcgroup.com/Portals/0/Monthly\%Performance/2012\%ASB\%1st\%20edition.pdf> accessed 10 September 2017.

${ }_{30} \quad B P \quad$ (n29)20; Nigerian National Petroleum Corporation, 'Oil Production' (September 2013)< http://www.nnpcgroup.com/NNPCBusiness/UpstreamVentures/OilProduction.aspx> accessed 10 September 2017.

${ }^{31} B P(\mathrm{n} 29)$.
} 

(a) is in Nigeria; or
(b) is under the territorial waters of Nigeria; or
(c) forms part of the continental shelfs; or
(d) forms part of the Exclusive Economic Zone of Nigeria. ${ }^{32}$

It is clear from a literal interpretation of the above provision that ownership, control and management of petroleum and natural gas throughout Nigeria are vested in the federal government to the exclusion of the federating states because the word 'State' within the meaning of the section refers only to the federal government In N. N. P. C. v. Famfa Oil Limited, ${ }^{33}$ the Supreme Court held that minerals, mineral oils and natural gas anywhere in Nigeria are vested in the federal government. To be sure, the power conferred on the federal government under the provision is total and complete as it combines both proprietary rights with right of governance and management of petroleum resources.

The provision of section 1 of the Petroleum Act is strengthened by the provisions of other legislation all of which but one were enacted by the federal military government as part of its policy of complete centralization of natural resource ownership and control. The relevant legislation include: Exclusive Economic Zone, Act, ${ }^{34}$ Territorial Waters Act 1967, ${ }^{35}$ Offshore Oil Revenue Decree 1971, ${ }^{36}$ Oil Pipelines Act 1965, ${ }^{37}$ Interpretation Act, ${ }^{38}$ and the Land Use Act 1978, ${ }^{39}$ For instance, Section 2(1) of the Exclusive Economic Zone Act 1978 vests sovereign and exclusive rights with respect to the exploration and exploitation of the natural resources of the sea bed, sub-soil and superjacent waters of the exclusive zone in the Federal Republic of Nigeria and such rights shall be exercisable by the federal government.

The effect of the above statutes on federal ownership and control of offshore petroleum resources came up for determination before the Supreme Court of Nigeria in A-G Federation v. A-G Abia State (No. 2), ${ }^{40}$ where the apex court held that based on the above statutes and the combined provisions of the Geneva Convention on the Territorial Sea and the Contiguous Zone 1958, Geneva Convention on the Continental Shelf 1958 and the United Nations Convention on the Law of the Sea 1982, sovereignty over offshore petroleum resources vest in the federal government of Nigeria to the exclusion of the federating states. Thus, petroleum resources including natural gas located offshore within Nigeria's territorial waters, exclusive economic zone and continental shelf are regarded as located within the territory of the Federation of Nigeria and outside the geographical territory of the federating states. It was further held by the Supreme Court that revenue which accrues to the federation account from offshore petroleum operations belongs to the entire Federation of Nigeria and not to the defendants' littoral oil-producing states for the purpose of the application of the principle of derivation pursuant to s.162 (2) of the 1999 Constitution. ${ }^{41}$

With respect to solid minerals, the relevant legislation is Nigerian Minerals and Mining Act 2007. ${ }^{42}$ Section 1(1) of the Act provides that the entire property in and control of all mineral resources in, under or upon any land in Nigeria, its contiguous continental shelf and all rivers, streams and water courses including the territorial waters and Exclusive Economic Zone is vested in the government of the federation. ${ }^{43}$ By the tenor of the Act ownership rights to solid mineral resources are vested exclusively in the federal government of Nigeria.

\footnotetext{
${ }^{32}$ Cap. P10 LFN 2004 as amended by the Petroleum (Amendment) Act No. 23 of 1996.

${ }^{33}$ N. N. P. C. v. Famfa Oil Ltd. (n16) 202; see also South Atlantic Petroleum Ltd. (n16).

${ }^{34}$ Cap. E17, LFN 2004.

${ }^{35}$ Cap.T5 LFN 2004.

${ }^{36}$ No. 9 of 1971

${ }^{37}$ Cap.O7 LFN 2004.

${ }^{38}$ Cap. 123 LFN 2004.

${ }^{39}$ Cap. L5 LFN 2004.

40 [2002] 6 NWLR (Part 764) 542, 828-9.

${ }^{41}$ The negative impact of this judgment on the revenue base of the littoral oil-producing States has been minimised with the enactment of the Allocation of Revenue (Abolition of the Dichotomy in the Application of the Principle of Derivation) Act 2004 which provides for the application of the principle of derivation to off-shore petroleum resources extracted within 200 metre water depth Isobath contiguous to a State of the federation. The same Supreme Court upheld the constitutionality of this Act in A-G Adamawa v. A-G Federation [2005] 18 N. W. L. R. (Pt. 958) 581, 673-4 on the ground that the Act merely provides for the application of the derivation principle to natural resources extracted within the specified maritime zone rather than granting ownership or control over those resources to the oil-producing states.

${ }^{42}$ Act No.20 of 2007.

${ }^{43}$ S.161 of the Nigerian Minerals and Mining Act 2007 repeals the Minerals and Mining Decree No. 34 of 1999.
} 
The above statutory provisions are reinforced and validated by s. 44(3) of the Constitution of the Federal Republic of Nigeria 1999 (as amended) which provides that:

s. 44 (3) Notwithstanding the foregoing provisions of this section, the entire property in and control of all minerals, mineral oils and natural gas in, under or upon any land in Nigeria or in, under or upon the territorial waters and the Exclusive Economic Zone of Nigeria shall vest in the Government of the Federation and shall be managed in such manner as may be prescribed by the National Assembly. ${ }^{44}$

There is no doubt that federal ownership of natural resources implies exclusive federal competence in the sphere of natural resource governance. This is indeed clear from s.4(2) and (3) of the 1999 Constitution (as amended) read together with item no. 39 in the Exclusive Legislative List, Second Schedule to the self-same Constitution which specify "mines and minerals, including oil fields, oil mining, geological surveys, and natural gas" as matters within the exclusive legislative competence of the National Assembly. Given that the executive powers of the federation which are vested in the President under s. 5(1) of the 1999 Constitution (as amended) extend to the execution of all laws made by the National Assembly and to all matters under its legislative competence, it stands to reason that the administration of all federal laws relating to natural resources in Nigeria and the governance of these resources are matters within the exclusive province of the executive organ of the federal government.

To complete the circle of federal competence over natural resources, s. 251(1)(n) of the 1999 Constitution (as amended) confers exclusive jurisdiction on the Federal High Court in all civil causes and matters arising from mines and minerals including oil fields, oil mining, geological surveys, and natural gas. Thus, from the tenor of the constitutional provision, the High Courts of the States of the federation lack the jurisdiction to entertain such matters. $^{45}$

Therefore, the position of the law in Nigeria is that no state of the federation, local government council, ethnic group, person or group of persons other than the federal government has any right of ownership or power of governance over natural resources. Thus, both onshore and off-shore petroleum and solid mineral resources and the governance of these resources vest exclusively in the federal government of Nigeria. To be sure, the statutory and constitutional provisions under reference make no distinction between ownership of petroleum resources that have been captured and taken into possession as opposed to those in situ. It is thus logical to conclude that federal government's ownership of petroleum resources in Nigeria is absolute and extends to all petroleum resources in place (in situ) and subject to the terms of particular contractual arrangement between the National Oil Company and the IOCs, to petroleum which has been extracted. Thus, the different theories of ownership of oil and gas are of no practical significance within the context of Nigerian ownership regime. ${ }^{46}$

Two clear incidents of exclusive federal ownership of natural resources in Nigeria may be highlighted here. First, the vesting of ownership and competence over minerals and petroleum resources in the federal government implies that it has the sole authority to grant oil rights and mineral titles to third parties to explore, prospect for and exploit the nation's vast natural resources subject to prescribed terms and conditions. The Petroleum Act 1969 and the Nigerian Minerals and Mining Act 2007 create two separate licensing regimes with respect to petroleum and solid minerals. ${ }^{47}$ The most striking feature of the two licensing regimes is that no person can engage in petroleum operations or mining activities in Nigeria without formal authorization by the federal government. These licensing powers are protected under s.13 (2) of the Petroleum Act and s. 2(1) of the Nigerian

\footnotetext{
${ }^{44}$ Cap. C23, Laws of the Federation of Nigeria 2004 (hereinafter '1999 Constitution' ); s. 44(3) of the 1999 Constitution re-enacts section 40(3) of the repealed Constitution of the Federal Republic of Nigeria 1979.

${ }^{45}$ S.P.D.C. Nigeria Ltd. v. Isaiah [2001]1 N.W.L.R. (Pt.723)169; C. G. G. (Nigeria) Limited v. Lawrence Ogu [2005] 8 N. W. L. R. (Pt. 927) 366,381 .

46 There are basically two theories of ownership: non-ownership theory and ownership theory. According to the non-ownership theory, since oil and gas in situ is migratory in character just like wild animals, fish, birds of the air and underground water, it is not capable of ownership until captured and taken into possession. Therefore, the owner of a parcel of land with oil in place, cannot claim ownership of the oil until it is drilled and brought to the surface, see Westmoreland \& Cambria Natural Gas Co. v. Dewitt, 130 Pa.235, 18 Atl. 724 (1889); State v. Ohio Co. 150 Ind. 21, 49 N. E. 19 (1898); the ownership theory on the other hand, postulates that the owner of a parcel of land is seised of the title to the oil and gas in situ beneath his land although his title may be defeated if the oil from his land migrates to the adjacent land and is produced from his neighbour's well. See generally, Howard R. Williams and Charles J. Meyers, Oil and Gas Law, Vol. 1 (Matthew Bender, New York 1985) 20-34.

47 S. 2 of the Petroleum Act, 1969 creates three types of mineral rights, namely Oil Exploration Licence, Oil Prospecting Licence and Oil Mining Lease; s. 46(1) of the Nigerian Minerals and Mining Act 2007 creates six classes of mineral titles, namely Reconnaissance Permit, Exploration Licence, Small Scale Mining Lease, Mining Lease, Quarry Lease and Water Use Permit.
} 
Minerals and Mining Act both of which criminalize unauthorized petroleum and mining operations.

Secondly, the power to raise revenue from the exploration and exploitation of Nigeria's petroleum and mineral resources under the different contractual arrangements also vests in the federal government. The 1999 Constitution (as amended) assigns export duties and the taxation of incomes, profits and capital gains (except as otherwise prescribed by the Constitution) to the National Assembly thus enabling the federal government to exercise fiscal power both in terms of legislation and administration over the petroleum sector. ${ }^{48}$ The fiscal power of the federal government over the sector is also prescribed in other enabling laws and covers fees, ${ }^{49}$ rents, ${ }^{50}$ royalties, ${ }^{51}$ petroleum profit tax,${ }^{52}$ penalties, bonuses, and crude oil sale receipts, etc. The enforcement of the fiscal regulations involves the collaborative efforts of different agencies of the federal government such as the NNPC, Directorate of Petroleum Resources (DPR) and the Federal Inland Revenue Service (FIRS). The NNPC receives and sells the federal government's share of crude oil from the IOCs under the different contractual arrangements. The collection of fees, royalties, penalties, rents, and bonuses is entrusted to the DPR while the FIRS are solely responsible for collecting petroleum profits tax.

It is indisputable from the licensing and fiscal regimes that no state of the federation is assigned any role in the entire process of managing and regulating the exploration and exploitation of the nation's natural resources. It is equally correct to state that as far as the control and management of the nation's natural resources are concerned, the regulatory agencies of the federal government such as the NNPC and DPR and the Minister responsible for petroleum resources and solid minerals are not subject to any form of control by the governments of the federating States in the exercise of their statutory powers. ${ }^{53}$ It is therefore legally permissible for the federal government or its regulatory agencies to grant oil rights and mineral titles to the IOCs or indigenous companies to explore and exploit natural resources located within the territories of a federating State without reference to the latter.

\section{Inequities of the Existing Governance Regime for Natural Resources}

The exclusion of the federating states, particularly the oil-producing states of the Niger Delta region of the federation, from the current ownership and governance regime for natural resources in Nigeria has had dire consequences for the oil-producing states and oil-bearing ethnic minorities of the Niger delta.

Nigeria's multi-ethnic federation comprises no less than 250 distinct ethnic groups made up of three majority ethnic groups of Hausa/Fulani, Yoruba and Igbo and 247 minority ethnic groups. Prior to the colonization of the political territory now called Nigeria, these disparate ethnic nationalities had existed as independent, separate and distinct entities, each exercising sovereignty within its own territory without any interference from the others. 54

It was these disparate ethnic groups that the British imperial power through a staggered process which commenced effectively on August 6,1861 with the execution of the Treaty of Cession of Lagos, subjugated, conquered and forcefully brought together to form a single political entity with the amalgamation of the Protectorate of Northern Nigeria and the Colony and Protectorate of Southern Nigeria on January $1,1914 .^{55}$ To be sure, the amalgamation itself which was recommended to the Colonial Office by the Niger Committee headed by Lord Selborne (1898) was conceived and executed by Britain without any input from the ethnic groups directly affected by it. The overriding consideration for the amalgamation of the two blocks of Nigeria as far as Britain was concerned, was the administrative convenience of using "funds available from the richer 'South' to offset the adverse financial standing of the less prosperous 'North' and so reduce fiscal dependence on scarce

\footnotetext{
${ }^{48}$ See item nos. 25 and 59 in the exclusive legislative list.

49 Petroleum Act, ss.3(3) and 4(4); Oil Pipeline Act, s. 7(2) and s. 31; Petroleum Regulations, regulation 58; Nigerian Minerals and Mining Act, ss. $55,61(\mathrm{j})$ and $70(\mathrm{~m})$.

${ }^{50}$ Petroleum Regulations, regulation 60, paras.1 and 2.

${ }^{51}$ Petroleum Regulations, regulation 61 para.1 (i)-(vii).

52 Petroleum Profits Tax Act, cap.P13, L. F. N. 2004, s.8.

${ }^{53}$ Oversight power over the petroleum and solid minerals sectors is vested in the National Assembly under ss. 88 and 89 of the 1999 Constitution.

${ }^{54}$ Attorney-General Federation (n1) 640; see also Biodun Adediran, "The origins of Nigerian peoples" in Richard Olaniyan (ed), Nigerian History and Culture (Longman Group Limited, Essex 1985) $10 ;{ }^{54}$ Federal Ministry of Information, "Nigerian Peoples and Their Cultures" (2016)< http://www. fmi.gov.ng/about-nigeria/history-people/\#tabs-127-0-1>accessed 25 September, 2017; Central Intelligence Agency, "The World Fact-book" (2016)<http://www.cia.gov/library/publications/the-world-factbook/geos/ni.html> accessed 25 September, 2017.

${ }^{55}$ See the Nigeria Protectorate Order-in-Council, 1913; ${ }^{55}$ Lord Milverton, "Nigeria" (1948) 47 African Affairs 80, 81.
} 
imperial grants-in-aid." 56

The result of the unholy marriage celebrated by the British imperial power between southern and northern Nigeria was the creation of a country made up of "nations and peoples who had no reason to think of themselves as members of a common society." ${ }^{, 57}$ Thus, Nigeria has remained largely a gathering of ethnic groups forcefully brought together by Britain without any unifying force. The resentment of the peoples of Nigeria against the amalgamation of 1914, which has been widely condemned as the "the mistake of 1914 " ${ }^{58}$ clearly justifies Awolowo's apt description of the country as an "abominable, disrupting and divisive British heritage. $" 59$

Clearly, the ethnocultural diversity of the peoples of Nigeria and the artificiality of the state itself have interplayed to produce a strong sense of ethnic consciousness and identity amongst the peoples of Nigeria that cannot be wished away. Put differently, in Nigeria, as in other parts of sub-Saharan Africa, subnational citizenship or citizenship at the ethnic group level provides a stronger bond of identity than national citizenship. ${ }^{60}$ Generally, therefore, loyalties are owed primarily to the ethnic groups or the administrative regions encompassing them, rather than the artificial entity called the "State" although the degree of ethnic allegiance to these groups may depend on the perception of the state by members of the diverse ethnic groups.

The provenance of ethnicity in Nigeria - the familial attachment of a person to his ethnic group which is manifested in a sense of allegiance or loyalty to the group - was recognized by the Constitution Drafting Committee (1976) which noted in its report that as a "general rule every Nigerian owes or is expected to owe some loyalty to his community and/or sub-community." ${ }^{61}$ Although the Committee equally noted that it was desirable that ethnic loyalty "ought not to be allowed to inhibit or detract from national loyalty, that is to say loyalty to the Nigerian State" ${ }^{62}$ the persistence of ethnicity in ethnically-plural Nigeria is too obvious to be disputed. ${ }^{63}$ As Glolabo Ogunsanwo, a public analyst, puts it, rather unapologetically:

Shorn of our hypocrisy, what we have are Yoruba-Nigerians, Hausa-Nigerians,

Fulani-Nigerians, Igbo-Nigerians and so on. We all proclaim loyalty to Nigeria publicly but behind our closed doors, our first loyalty is to our various tribes. ${ }^{64}$

A survey carried out in Northern Nigeria about 1967 suggested that 74 percent of the respondents aged 17 years agreed that a person's loyalty "should be to his region, rather than to his country." ${ }^{.65}$ And much later in 2000, a survey of public opinion involving a random sample of 3,603 respondents found that ethnic identity was the strongest form of identity among Nigerians. The survey revealed that "almost half of all Nigerians (48.2 percent) chose to label themselves with an ethnic identity, compared to almost one third ( 28.4 percent) who opted for class identity. ${ }^{66}$ Although another 21.0 percent of the sample opted for a religious identity, the survey did not suggest that a sense of national identity was totally lacking. On the contrary, it was found that 97.2 percent of the respondents agreed that "they were proud to call themselves Nigerians" although "they felt just as strongly about

\footnotetext{
${ }^{56}$ Tekena N. Tamuno, "Nigerian Federalism in Historical Perspective" in Kunle Amuwo, Adigun Agbaje, Rotimi Suberu, et al, Federalism and Political Restructuring in Nigeria (Spectrum Books Limited, Ibadan 1998) 13, 15.

${ }^{57}$ B. R. Rubin and J. B. Asuni, 'Transition, a new opportunity to transform Nigeria's numerous conflicts' in M. Mekenkamp et al. (eds), Searching for Peace in Africa: An overview of Conflict Prevention and Management Activities (European Platform for Conflict Prevention and Transformation/ African Centre for the Constructive Resolution of Disputes, Utrecht 1999)332.

${ }^{58}$ Tekena N. Tamuno, "Separatist Agitations in Nigeria since 1914" (1970) 8 (4) Journal of Modern African Studies 563,565; see also Sir Ahmadu Bello, My Life: The Autobiography of Sir Ahmadu Bello (Cambridge University Press, Cambridge 1962)133.

${ }^{59}$ Obafemi Awolowo, The People's Republic (OUP, Ibadan 1968) 69.

${ }^{60}$ John Boye Ejobowah, "Who owns the oil? The politics of ethnicity in the Niger delta of Nigeria" (2000) 47 Africa Today $28,32$.

${ }^{61}$ Federal Republic of Nigeria, Report of the Constitution Drafting Committee containing the Draft Constitution, Volume 1 (Federal Ministry of Information, Lagos 1976) viii.

${ }^{62}$ Report of Constitution Drafting Committee (n61) viii.

${ }^{63}$ The term 'ethnicity' is also used to define the behaviour of members of ethnic groups within the larger political community or the employment of ethnic identity to secure advantage or promote cooperation, collaboration or conflict. See Ukoha Ukiwo, "The study of ethnicity in Nigeria" (2005) 33 Oxford Development Studies 7, 8; Eghosa E. Osaghae, Structural Adjustment and Ethnicity in Nigeria (Nordic African Institute, Uppsala 1995) 11; Joshua A. Fishman, "Language, ethnicity and racism" in Joshua A. Fishman et al (eds), The Rise and Fall of the Ethnic Revival (Mouton Publishers, Berlin 1985) 3, 4.

${ }^{64}$ The Comet (July 23, 2000) 11.

${ }^{65}$ Times Monthly Supplement (New York, March 1967) reporting a survey of 600 northern Nigerians, cited in Donald L. Horowitz, Ethnic Groups in Conflict (University of California Press, Berkeley 1985) 6-7.

${ }^{66}$ Peter Lewis and Michael Bratton, "Attitudes to democracy and markets in Nigeria" Afrobarometer Paper No. 3 (The Institute for Democracy in South Africa Cape Town, April 2000) 24-25.
} 
this national identity as about their sub-national group identity. ${ }^{, 67}$

The provenance of ethnicity in Nigeria implies that ethnic identity is often employed or mobilized to gain advantage in situations of competition, conflict or cooperation, thus making it the defining feature of politics. ${ }^{68}$ In relation to the business of government, this translates into an entrenched practice whereby the exercise of governmental power is often influenced by ethnic considerations with the result that federal power is usually appropriated for the benefit and advantage of the particular ethnic groups that control the lever of political power at the centre.

Considering, therefore, that Nigeria's ethnic configuration gives a decided advantage to the three majority ethnic groups of Hausa/Fulani, Yoruba and Igbo which has been employed effectively to control the federal government, it is very arguable that the exercise of federal power often reflects the interests of these dominant ethnic groups. In relation to natural resources, the reality of Nigerian ethnic politics implies that federal ownership of these resources translates into their virtual control by the three majority ethnic groups to the disadvantage of the ethnic minorities of the Niger Delta.

Put differently, since Nigerian politics is all about securing access to the vast oil wealth generated from the Niger Delta, access to political power at the centre guarantees access to oil wealth. ${ }^{69}$ Access to oil wealth in turn, confers enormous advantages on the dominant ethnic groups in terms of the redistribution of the benefits from oil and gas operations. Thus, with an effective system of patronage driven by ethnic loyalties, benefits accruing from the oil and gas sector have been dispensed to members of the majority groups thereby further entrenching their dominance in the federation.

It is submitted, therefore, that the reality of Nigerian oil politics is that the centralization of natural resource ownership and governance has become a veritable tool of ethnic and political domination by the majority ethnic groups against oil-producing communities of the Niger Delta. Armed with political and economic powers, the bulk of the oil wealth produced from the Niger Delta is "captured by the federal state and distributed to the so-called 'ethnic majorities' in the politically dominant northern and western states." 70 Through this oppressive employment of their demographic, political and economic superiority, resources have been transferred from the Niger Delta to establish industries, build federal government institutions and develop key infrastructure in the dominant regions while leaving behind a neglected and weak periphery. It is within this context that the criminal neglect of the Niger Delta by successive federal administrations in spite of decades of exploitation of hydrocarbons by the Nigerian State can have real meaning.

Unarguably, the infrastructural backwardness of the Niger Delta and the abysmal poverty of its people in spite of decades of petroleum production are clearly part of the orchestrated marginalization of the Niger Delta minorities by the majority groups. The marginalization also accounts for the failure of the federal government to address the ecological and environmental externalities associated with oil and gas production which have completely crippled the traditional economy of the region and affected the quality of lives of its peoples. ${ }^{71}$

Thus, the current natural resource ownership and governance regime in Nigeria has produced two major pathologies. First is that although as earlier demonstrated, all of Nigeria's crude oil is produced from the land and swamps of the Niger delta region and from deep-water reserves some 120 kilometres off its coast, the ethnic minorities of the region "belong to the ranks of the most backward and politically marginalized groups in the country. ${ }^{72}$ The Niger delta ethnic groups traced this horrendous injustice to the fact that they are ethnic minorities in a federation dominated by the Hausa/Fulani, Yoruba and Igbo ethnic groups and that they are denied access to the vast oil wealth generated from their region which is used to develop other regions of the federation. ${ }^{73}$

\footnotetext{
${ }^{67}$ Lewis and Bratton (n66) 25.

${ }^{68}$ Osaghae (n63) 11.

${ }^{69}$ Xavier Sala-i-Martin and Arvind Subramanian, 'Addressing the natural resource curse: An illustration from Nigeria’ Working Paper No. 9804 (National Bureau of Economic Research, Cambridge June 2003) 13

$<$ http://www.nber.org/papers/w9804/>accessed 02 July, 2017.

${ }^{70}$ Michael Watts, 'Crude politics: Life and death on the Nigerian oil fields' Niger Delta Economies of Violence Working Paper No. 25 (Institute of International Studies University of California Berkeley USA, 2009) 18

$<$ http://oldweb.geog.berkeley.edu/ProjectsResource/ND\%20Website/NigerDelta/WP/Watts_25.pdf/>accessed 07 July, 2017.

${ }^{71}$ Ibibia Lucky Worika, 'Deprivation, despoilation and destitution: Whither environment and human rights in Nigeria's Niger delta?' (2001-2002) 8 ILSA J. Int'l \& Comp. L. 1, 5.

${ }^{72}$ Eghosa E. Osaghae, 'The Ogoni uprising: Oil Politics, Minority Agitation and the future of the Nigerian State' (1995)94 African Affairs 325.

${ }^{73}$ Ijaw National Congress (INC), The Ijaws, the Niger Delta and the Nigerian State (University of Port Harcourt Press, 2006$) 13$.
} 
Secondly, oil exploitation spanning over five decades has left in its trail severe environmental degradation, despoliation of the ecosystem and destruction of the peasant economy of the region built on fishing and farming thereby exposing the people to severe health hazards, economic hardship and social dislocation. ${ }^{74}$ Given that the region is denied any right of participation in the decision making process concerning resource governance, these externalities have persisted without any genuine commitment by the central government to address them.

The 2006 Report by the United Nations Development Programme (UNDP) painted a shocking and grim picture of the Niger delta: "In reality, the Niger Delta is a region suffering from administrative neglect, crumbling social infrastructure and services, high unemployment, social deprivation, abject poverty, filth and squalor, and endemic conflict. ${ }^{75}$ The Report chronicled the lack of basic infrastructure and amenities in the region such as electricity, roads, schools, hospitals, potable water, and housing and concluded that although oil wealth enriches Nigeria as a country, "it has not alleviated the grinding poverty, neglect and deprivation in the region that produces it." ${ }^{176}$ The findings in the UNDP's Report are amply supported by a number of other reports and studies including those commissioned by the federal government. ${ }^{77}$ Attention may be drawn here to just two of such reports. The Report of the Technical Committee on the Niger Delta discussed the infrastructural poverty of the Niger Delta communities and concluded that:

They still lack basic facilities and amenities that are taken for granted in other parts of the country. In particular, the creeks and riverine areas still look worse than the fourth world by whatever development indicators that may be applied. Some of the riverine communities cannot be accessed by road, have no school, clinic or any form of electricity. . . The absence of such infrastructure in a region that produces so much wealth and opportunities for the nation has continued to prick the conscience of many and contaminate opportunities for building national harmony and a sense of citizenship. ${ }^{78}$

The Report by Amnesty International is no less damning in its vivid description of the striking contrast between the enormous resource wealth of the Niger delta and its shocking underdevelopment and neglect:

Oil has generated an estimated $\$ 600$ billion since the 1960 s. Despite this, the majority of the Niger delta's population lives in poverty. . . The majority of the people of the Niger delta do not have adequate access to clean water or health care. Their poverty, and its contrast with the wealth generated by oil, has become one of the world's starkest and most disturbing examples of the 'resource curse. ${ }^{, 79}$

\section{A New Natural Resource Ownership and Governance Regime}

This paper has already demonstrated the need for reform of Nigeria's centralized state ownership of natural resources on the grounds that the system serves not only as a tool of ethnic domination but also ensures the neglect of the oil-producing Niger delta region. A further ground is that the current regime is exploitative, inequitable and unjust to both the oil-bearing communities and oil-producing states in the Niger Delta region.

However, in formulating any proposals for an equitable resource ownership and governance regime, four critical factors must be considered if such proposals are to stand the test of time. First, Nigerian federalism is symmetrical in character. All the constituent states of the federation stand on equal footing in relation to the central government and no state of the federation is granted any special right or interest to the exclusion of other states under the 1999 Constitution (as amended). Accordingly, any proposals for addressing the inequities in the Nigerian federal system with respect to natural resource ownership and management must be applicable to all states of the federation irrespective of whether the state is oil-producing or not.

Secondly, having regard to the fact that "federalism is not a fixed point on a map, but a tendency which is neither

\footnotetext{
${ }^{74}$ Ijaw National Congress (n74) 18-22; Chris O. Ikporukpo, 'Petroleum, Fiscal Federalism and Environmental Justice in Nigeria' (2004) 8 Space and Polity 321, 325-330.

75 UNDP, 'Niger Delta Human Development Report' (UNDP, Abuja Nigeria 2006) 9<http://hdr.undp.org/en

/reports/nationalreports/africa/nigeria/name, 3368, en.html/>accessed August 27, 2017.

${ }^{76}$ UNDP (n75) 37.

${ }^{77}$ Some of these Reports include; Report of the Ministerial Fact-Finding Team to Oil Producing Communities in Nigeria, 1994; Report of the Presidential Committee on the Development Options for the Niger Delta, 1996.

${ }^{78}$ Report of the Technical Committee on the Niger Delta, Vol. 1 (Abuja, November 2008) 50-1.

79 Amnesty International (n25); see also Amnesty International, 'Annual Report 2013'(London, 2013) 196<http://www.amnesty.org/en/annual-report/2013 > accessed 08 August 2017.
} 
unitary nor separatist," 80 it seems logical that a balance must be maintained always between two contending interests, that is, "not just preserving state authority where appropriate, but also enabling the federal government to act where national action is desirable." 81 The balancing of both interests demands a nuanced approach to the question of allocation of rights and powers over natural resources.

Thirdly, any credible reform option must seek to incorporate the underlying principles of Nigeria's federalism by protecting the ethnic minorities against domination by the majority groups while also encouraging the constituent units, each to develop at its own pace along its characteristic lines.

Finally, given that natural resources are unevenly distributed across geographic regions, there are invariably resource-rich and resource-constrained states within the federation with varying levels of fiscal capabilities. These disparities call for a system that balances the need for local control over natural resources with the equally competing national need to bridge inter-regional economic disparities. Thus, the benefits derivable from natural resources extracted from any region of the federation cannot be confined to the region of origin. Put differently, each state of the federation is entitled to the benefits of the federal union in relation to natural resources extracted from any part of the federation. Therefore, the best reform option is one which is capable of bridging the disparities through a fiscal equalization arrangement whereby revenue derived from the resource-rich region is redistributed to the resource-constrained regions. ${ }^{82}$

One major rationale for this approach is that horizontal disparities in wealth and services among constituent units of a federation are inimical to federal stability. ${ }^{83}$ Fiscal equalization is also justified on the ground that all citizens within a federation "should be entitled to comparable services without having to be subject to excessively different tax rates." across regions from the better off to the worse off in order to achieve redistributive justice. ${ }^{85}$ The redistributive role of the state could help in strengthening a sense of national community.

This paper proposes a decentralized system of natural resource ownership and governance founded on shared competences between the federal government and the federating states. To be sure, the phrase 'shared competences' is used to "describe a situation in which both levels of government are assigned sub-aspects within the same policy fields." " governments in resource ownership and governance as a means of protecting and preserving national and regional interests in natural resources. This will require the federal government devolving part of its powers over natural resources to the federating states in the manner set out hereinafter.

Another feature of the proposed system is the existence of a fiscal equalization arrangement that is designed to achieve distributive justice. The underlying principle of the proposal is that given the grounds argued in this work, the continued suppression of regional interests in natural resource ownership and development by the Nigerian State has become ethnically divisive and that only the accommodation of both interests in natural resources can conduce to the stability of the federation.

The starting point of the proposal is that the federal government should devolve rights of ownership and control over onshore natural resources to the federating states with the exception of onshore natural resources found within the Federal Capital Territory, Abuja, which should continue to vest in the federal government by virtue of sections 297(2) and 299 of the 1999 Constitution (as amended). It is further proposed that the devolved powers should include the rights of the federating states to own and manage onshore natural resources through negotiating and granting of leases, licences and other mineral rights for exploration and production activities. This arrangement would enable the federating states to be actively involved in the decision-making process concerning natural resource governance and thereby minimize the domination of oil-producing minorities by a powerful centre that serves the interests of the majority ethnic groups.

\footnotetext{
${ }^{80}$ Frank C Trager, 'Introduction on federalism' in Thomas M. Franck (eds.), Why Federations Fail (New York University Press, NY 1968) ix, $\mathrm{x}$.

${ }^{81}$ Larry Kramer, "Understanding federalism" (1994) 47 Vand. L. Rev. 1485, 1502.

82 Madu Onuorah, "NNPC discovers oil in Lake Chad Basin" The Guardian (Lagos, September 8, 2012)<http://www.ngrguardiannews.com/index.lake-chad-basin/ $>$ accessed September 8, 2017

${ }^{83}$ Ronald L. Watts, "Equalization in commonwealth federations" (2003) 13 Regional \& Federal Studies 111, 112-113.

${ }^{84}$ Watts (n83) 112.

${ }^{85}$ Allen Buchanan, "Federalism, secession, and the morality of inclusion" (1995) 37 Ariz. L. Rev. 53, 57-58.

${ }^{86}$ Nicole Bolleyer and Lori Thorlakson, "Beyond decentralization: The comparative study of interdependence in federal systems" (2012) 42 Publius: The Journal of Federalism 566, 571.
} 
Arguably, the legislative competence of the federal government over inter-state trade and commerce, international trade, exports and external affairs under the 1999 Constitution (as amended) implies that its participation in the sphere of natural resources is an entrenched element of Nigerian federalism even under a devolved system of resource ownership and governance. In other words, federal competence over these matters gives it substantial control over the exploration and exploitation of natural resources. Thus, retaining the current constitutional arrangement whereby the federal government exercises exclusive legislative competence over natural resources will not be inconsistent with the devolution proposed herein. Therefore, it is proposed that item 39 in the exclusive legislative list, Second Schedule to the 1999 Constitution which vests the National Assembly with competence over 'mines and minerals, including oil fields, oil mining, geological surveys, and natural gas', should be retained in its current form.

The effect of this proposed arrangement is that while the proprietary rights over onshore natural resources, including control to the extent already defined, will vest in the federating states, the legislative competence over these resources will continue to be retained by the federal government. Thus, the federating states would be required to exercise their proprietary rights over onshore natural resources including the conditions and terms for granting mineral titles in accordance with the provisions of applicable federal laws. It is submitted that apart from making for uniformity and assuring predictability in the legal and regulatory framework for the sector, this proposal would ensure that the regulatory regime is sufficiently protective of the interests of the constituent states in their dealings with the IOCs given the institutional capacity already developed by the federal government in this sector.

Furthermore, it is clear from the observations of Lord Herschell in A-G., Canada v. A-G., Ontario, ${ }^{87}$ that there is no inconsistency in separating rights of ownership from legislative competence and vesting them in different levels of government. The practice of resource federalism in India, Ethiopia and Malaysia also shows that the allocation of ownership rights and legislative powers to separate jurisdictions or vesting ownership jointly in two jurisdictions as is the case in Pakistan and Russia can be utilized to accommodate both national and regional interests in natural resource development. ${ }^{88}$

Specifically in India, the 1949 Constitution creates a dual regime whereby rights of ownership (dominion) and governance or control (imperium) over natural resources are placed under different constitutional jurisdictions. By virtue of Arts.294 -295 of the Constitution of India 1949, each state of the Federation is vested with ownership of land and natural resources located within its territory excluding off-shore natural resources which are owned by the central government under Article 297 of the Constitution. Accordingly, ownership of all on-shore petroleum and mineral oil resources vest in the respective states of the federation. However, control and development of these resources vest with the central government by virtue of Art.246(1) and Item 53 in List 1 of the Seventh Schedule to the Constitution which confer exclusive competence on parliament with respect to 'Regulation and development of oilfields and mineral oil resources; petroleum and petroleum products.' Therefore, the exclusive competence to enact relevant laws for the regulation and development of oil and mineral resources including those owned exclusively by the states vests in the central government. ${ }^{89}$

As an incident of resource ownership, the states in the Federation of India are entitled to grant leases and licences for exploration and exploitation of onshore petroleum resources in addition to collecting fees, taxes and royalties but subject to and in accordance with central laws which prescribe the terms and conditions therefore. Under Rule 5(ii) of the Petroleum \& Natural Gas Rules 1959 licences and leases can only be granted by the states for the exploration and exploitation of petroleum with the previous approval of the central government. Similarly, s. 6A of the Oilfields (Regulation and Development) Act 1948 gives the central government the power to fix and revise the rate of royalty payable for licences and leases granted by the states. Taxation of mineral rights by the states is also subject to limitations imposed by central legislation. The combined effect of these provisions is that the exercise by the states of their proprietary rights in onshore petroleum resources is subject to the regulatory authority of the central government.

A similar practice of shared competences in natural resource ownership and development obtains in Ethiopia where Art.52 (2) (d) of the Constitution of the Federal Democratic Republic of Ethiopia 1994 empowers states to administer land and other natural resources in accordance with federal laws. Article 51(5) of the Constitution

\footnotetext{
${ }^{87}$ [1898] AC 700, 709

${ }^{88}$ George Anderson, "Reflection on oil and gas in federal systems" in George Anderson (ed.), Oil and Gas in Federal Systems (OUP, Ontario 2012) $371,378-379$

${ }^{89}$ The Petroleum \& Natural Gas Rules, 1959 (as amended), rules 6, 11, 13 and 14; The Oilfields (Regulation and Development) Act, No. 53 of 1948 (as amended), s.4; Ligia Noronha and Nidhi Srivastava, "India" in Anderson (n88) 121, 129-30.
} 
vests the federal government with power to enact laws for the utilization and conservation of land and other natural resources. Through this system of shared competences, while states manage natural resources within their respective boundaries the federal government provides the regulatory framework for the natural resource industry. This practice is also reflected in the assignment of tax jurisdictions because by Art.98(3) of the Constitution the federal and state governments shall jointly levy and collect taxes on incomes derived from large scale mining and all petroleum and gas operations including royalties on such operations

The proposal on retaining federal legislative competence over natural resources contrasts with two existing recommendations on the point. The first is the submission of the Mid-Western Nigeria delegation to the $1966 \mathrm{Ad}$ Hoc Constitutional Conference which recommended that mines and minerals, including oil fields, oil mining, geological surveys and natural gas, should be assigned as residual matters to regional governments. ${ }^{90}$ The second is the recommendation of the Committee on the Executive of the 1994-1995 Constitutional Conference to the effect that mines and minerals should be treated as concurrent matters with offshore resources reserved to the federal government and onshore resources assigned to states. ${ }^{91}$

For the reasons already set out above, it could be argued that granting states residual or concurrent legislative jurisdiction would not strengthen their position in any significant manner as long as they are guaranteed right of participation in resource ownership and governance. Arguably, the strategic importance of the sector to the national economy does not support vesting states with residual legislative jurisdiction as such arrangement will conflict with federal supremacy in other spheres. Besides, in the realm of concurrent jurisdiction, federal laws will always prevail over state laws and Nigerian federal practice shows that for concurrent matters, federal legislation will always cover the field. On balance, therefore, it is submitted that federal legislative jurisdiction accords with Nigeria's national interest.

This brings us to the recommendation of the National Constitutional Conference, 2014 that mines and minerals, including oil fields, oil mining and geological surveys and natural gas should continue to be retained as legislative items on the exclusive legislative list provided that the governments of states where the mining activities take place shall be involved in matters relating thereto and that the federal government shall create a special fund for the development of mines and minerals in states where such resources are undeveloped. ${ }^{92}$ While the retention of federal legislative competence over natural resources is agreeable, it is difficult to define the level of involvement of oil-producing states in mining activities as recommended by the Conference. Clearly, the participation of oil-producing states in the development of natural resources within their geographic territories must derive from their proprietary interests in the resources. It is, therefore, inconceivable to recommend participation of oil-producing states in natural resources development without vesting of proprietary interest over the resources in the states.

In order to guarantee effectiveness, the proposals herein formulated depart from the Indian model which requires that leases and licences granted by states in exercise of their proprietary rights over onshore natural resources shall receive the prior approval of the union government. It is very arguable that granting such discretionary power to the central government without the involvement of state governments would amount to subjecting the latter to the tyranny of the former. Given that such arrangement could defeat the very essence of the reform which is to minimize the domination of the oil-bearing units in the development of natural resources, it is suggested that an inter-govern-mental agency with representatives drawn from both levels of government should be established and assigned the responsibility for considering and granting such approvals to state governments.

Offshore natural resources demand different considerations. Given that the sovereign rights to explore and exploit offshore resources vest in the coastal state under international law, it is within the competence of the government of the federation as the person of international law to devolve these proprietary rights within designated areas of the maritime belt to the governments of the constituent states in accordance with the provisions of its municipal law. ${ }^{93}$ The power of the federal government to make such grant derives from the fact that the sovereign rights to explore and exploit offshore natural resources are vested in the coastal state which, in

\footnotetext{
${ }^{90}$ Memorandum Submitted by the Delegations to the Ad Hoc Conference on Constitutional Proposals for Nigeria (Nigerian National Press Ltd, Apapa 1967) 70, 73.

${ }^{91}$ Federal Republic of Nigeria, 'Reports of the constitutional conference containing the resolutions and recommendations Vol. II' (Nigerian Government Printer, Lagos 1995) 76; this recommendation was rejected by the conference.

${ }^{92}$ Report of National Constitutional Conference (Abuja, 2014) 138.

${ }^{93}$ The exercise of this power by the US Congress was based on Art. IV, §3(2) of the US Constitution and confirmed by the US Supreme Court in Alabama v. Texas, 347 U.S. 272 (1954); R.R. Churchill and A.V. Lowe, The Law of the Sea (Manchester University Press, Manchester 1983) $121-122$.
} 
a federation, comprises the federal government and the governments of the federating states. Furthermore, the coastal state can utilize its municipal law to regulate the distribution of these rights between the federal and regional governments in any manner it chooses. As Churchill and Lowe put it:

How the State chooses to distribute rights of ownership or control or both between federal and provincial governments is a matter to which international law is completely indifferent. The allocation is a matter left entirely to municipal law. ${ }^{94}$

Deriving from the above, it is proposed that the federal government should devolve to the littoral States rights of ownership over offshore resources found or extracted within three nautical miles from their coastline subject to federal regulations. This proposal is informed by the fact that since section 1(1) of the Territorial Waters Act 1967 defines the territorial waters of Nigeria to "include every part of the open sea within twelve nautical miles of the coast of Nigeria (measured from low water mark) or of the seaward limits of inland waters", the grant of proprietary titles to littoral states over natural resources of the seabed and sub-soil within the three mile belt of the territorial waters leaves resources within the remaining part of Nigeria's territorial waters, the continental shelf and exclusive economic zone, to the control of the federal government. Apart from the fact that this proposal reflects a common practice among federations, it is arguable that offshore exploration and exploitation could have adverse environmental impact on littoral states. The limited participation of these states in the field would not only serve to protect their interests but will also conduce to peace in the region.

\section{Concluding Remarks}

The current regime of natural resource ownership and governance is unarguably one of the most divisive features of Nigeria's federalism and there is no doubt that its reform is long over- due. The ethnic tension that pervades the land is traceable in part to the horrendous injustice that centralization of natural resource ownership and governance has inflicted on the oil and gas producing Niger Delta region of the Federation. A system that assigns no role to the oil-producing states in the entire scheme of resource governance is most unjust as it leaves the oil-producing states at the mercy of the central government and its agencies and their citizens vulnerable to the environmental, ecological, social and economic externalities associated with resource extraction.

The current system of resource governance is not sustainable in Nigeria's federalism because it derogates from its twin underlying principles that no region should suffer domination from another and that the constituent units should be encouraged to develop each at its own pace along its characteristic line. The fear that resource federalism will deprive resource-constrained regions of revenue derived from natural resources is unfounded because as our proposals clearly show, every region in the federation will continue to derive benefits from natural resources located within the Federation.

Finally, the current trend in resource federalism in most federations is that natural resource ownership and governance are treated as both national and regional concerns, rather than matters within exclusive national competence. The need for shared competences over natural resources between levels of government in a federation is far more compelling in an ethnically divided polity like Nigeria where the exercise of governmental power is often influenced by ethnic considerations with the result that federal power over natural resources has largely been appropriated for the benefit and advantage of those ethnic groups that dominate the lever of political power at the federal level.

\footnotetext{
${ }^{94}$ R. R. Churchill and A. V. Lowe, The Law of the Sea (Manchester University Press, Manchester 1983)121-2.
} 